\title{
4131: Developing economic thresholds for stink bugs in rice - problems and prospects
}

\author{
Friday, September 30, 2016 \\ 03:30 PM - 03:45 PM \\ P Convention Center - Room W230 C
}

Introduction: The relationship between injury and yield loss is central to the economic injury level (EIL) concept. However, establishing quantitative relationships between populations, injury and yield is difficult for piercing/sucking insects. Stink bug injury in rice is difficult to quantify because feeding occurs over an extended period of time and the injury is initially indistinct. Yield is lost through the combined effects of injury and time.

Methods: We conducted field experiments to determine the relationship between Tibraca limbativentris infestation and rice yield loss. Experimental design involved randomized complete blocks with at least four replications. Treatments consisted of stink bug infestations at different population densities. Yield was regressed against stink bugs $/ \mathrm{m}^{2}$ and slope of the linear regression was used as the yield loss/insect density variable in EIL calculations.

Results/Conclusion: Although T. limbativentris can produce large numbers of "dead hearts" and "white panicles", under normal conditions (reasonably fertile soil, limited use of insecticides) yield loss can have limited economic significance. However, stink bugs and "dead hearts" are highly visible and create farmer perceptions of considerable damage. Alternative methods for assessing the need for therapeutic action are required. One approach may be to set targets for the number of undamaged panicles per unit area to optimize yield, rather than to have responses triggered by the number that are damaged. The insect/day approach is other useful tool that could be used to measure the intensity of stink bug attack on rice plants, because it combines the number of insects and the duration of their feeding.

doi: 10.1603/ICE.2016.93983

\section{Authors}

José Alexandre Freitas Barrigossi

Embrapa Arroz e Feijão

Daniel F. Caixeta

Uni-Evangélica

Tavvs M M. Alves

University of Minnesota

\section{View Related Events}

Symposium: 628 Symposium: Global Challenges in Rice Pest Management

Program: Symposium

Day: Friday, September 30, 2016 